\title{
ANALISIS SIMULTAN SEKTOR MONETER DI INDONESIA (PENDEKATAN PARSIAL MUNDELL-FLEMING)
}

\author{
Aula Ahmad Hafidh Saiful Fikri \\ Universitas Negeri Yogyakarta, Indonesia \\ aula_hsf@uny.ac.id
}

\begin{abstract}
Abstrak: Kebijakan moneter merupakan salah satu usaha pemerintah untuk mengendalikan keadaan ekonomi makro. Perubahan yang terjadi pada kebijakan moneter akan mempengaruhi variabel-variabel ekonomi yang lain. Berdasarkan hal tersebut, studi ini bertujuan untuk melakukan analisis secara simultan shocks kebijakan moneter dalam perekonomian terbuka terhadap variabel-variabel ekonomi dengan menggunakan data Indonesia periode 2000:1 - 2019:8 dengan menggunakan pendekatan secara parsial Teori Mundell-Fleming. Metode yang digunakan dalam studi ini adalah Two-Stage Least Square (TSLS). Hasil yang diperoleh dalam studi ini menunjukkan bahwa (1) shock kebijakan moneter terhadap variabel-variabel ekonomi menunjukkan adanya suatu fenomena puzzle atau tidak sesuai teori dan (2) kontribusi BI rate yang paling besar dirasakan oleh variabel harga (inflasi). Penelitian ini memakai model IS-LM parsial dari sisi LM. Hasil penelitian menunjukan bahwa ada hubungan simultan antara variabel endogen persamaan tingkat bunga dan inflasi. Dari model persamaan tingkat bunga semua variabel mempunyai pengaruh yang signifikan terhadap tingkat bunga kecuali harga minyak dunia (OP). hubungan negatif ditunjukkan oleh permintaan uang (MD), pendapatan nasional (IPI) dan inflasi (INF). Sedangkan dalam persamaan inflasi, hanya variabel IPI yang tidak signifikan, hubungan negatif ditunjukkan oleh IPI dan aset luar negeri bersih (NFA).
\end{abstract}

Kata Kunci: Suku Bunga, Inflasi, Persamaan Simultan, Mundell-Fleming

\section{MONETARY SECTOR SIMULTANTS ANALYSIS IN INDONESIA (MUNDELL- FLEMING PARTIAL APPROACH)}

\begin{abstract}
Monetary policy is one of the government's efforts to control macroeconomic conditions. Changes in monetary policy will affect other economic variables. This study aims to simultaneously analyze monetary policy shocks in the open economy using Indonesian monthly data for the period 2000:1 - 2019:8 using a partial approach to the Mundell-Fleming Theory. The method used in this study is Two-Stage Least Square. The results obtained indicate that (1) the shock of monetary policy on economic variables indicates phenomenon of puzzle or not according to theory and (2) contribution Bank Indonesia rate is the biggest to the price variable (inflation). This study uses a partial IS-LM model from the LM side. The results showed that there was a simultaneous relationship between the endogenous variables of the interest rate equation and inflation. From the interest rate equation model, all variables have a significant effect on the interest rate, except for the world oil price, negative relationship is shown by money demand, national income and inflation. Meanwhile, in the inflation equation, only the national income variable is insignificant, a negative relationship is shown by national income and net foreign assets.
\end{abstract}

Kata Kunci: Interest Rate, Inflation, Simultaneous Equation, Mundell-Fleming 
Jurnal Ekonomi \& Pendidikan, 18(1), 2021

\section{PENDAHULUAN}

Globalisasi dan keterbukaan ekonomi telah mendorong integrasi pasar keuangan dan perekonomian berbagai negara (Grilli \& Milesi-Ferretti, 1995). Salah satu dampak integrasi tersebut adalah semakin mudahnya pergerakan arus modal antar negara. Masuknya arus modal ke dalam suatu perekonomian di satu sisi bermanfaat untuk menunjang ketersediaan sumber dana investasi, memfasilitasi terjadinya transfer teknologi dan kemampuan manajerial serta mendorong perkembangan pasar keuangan domestik. Selain itu, arus modal masuk ke suatu negara juga akan mendorong efisiensi alokasi sumber daya secara global, perbaikan alokasi dana dan mengatasi permasalahan investment-saving gap yang pada umumnya terjadi di negara-negara sedang berkembang. Dalam kondisi demikian, menjaga stabilitas perekonomian tidaklah mudah. Kejadian ekonomi yang terjadi secara global, baik secara langsung maupun tidak langsung, memberikan pengaruh terhadap perekonomian Indonesia. (Purba, 2018) Kondisi perekonomian global yang kurang menguntungkan, terutama meningkatnya harga minyak dunia dan siklus pengetatan kebijakan moneter global, menyebabkan upaya menjaga momentum stabilitas ekonomi makro mengalami gangguan yang cukup berarti. (Retnasih et al., 2016)

Dalam suatu sistem perekonomian, salah satu cara untuk mengendalikan keseimbangan ekonomi adalah melalui kebijakan moneter. Kebijakan moneter merupakan suatu usaha pemerintah dalam mengendalikan keadaan ekonomi makro agar dapat berjalan sesuai dengan yang diinginkan. Kebijakan moneter pada dasarnya adalah suatu kebijakan yang bertujuan untuk mencapai keseimbangan internal (stabilitas harga) dan keseimbangan eskternal (nilai tukar) serta tercapainya tujuan ekonomi makro yaitu menjaga stabilitas ekonomi yang dapat diukur dengan kesempatan kerja, kestabilan harga, serta neraca pembayaran internasional yang seimbang. Fokus penerapan kerangka kebijakan moneter pada Negara-negara di dunia saat ini adalah pada pengendalian laju inflasi (inflation targeting). Keberhasilan kebijakan ini dapat dinilai dari bagaimana efektivitas kebijakan dalam menunjang pertumbuhan ekonomi dan menjaga kestabilan laju inflasi pada jangka panjang, meskipun dalam penerapannya banyak ahli ekonomi yang mengkritik. Hal itu disebabkan karena terdapat trade-off antara pertumbuhan ekonomi dan laju inflasi dalam jangka pendek yang sering digambarkan dalam kurva philip jangka pendek. (Solikin, 2008)

Dalam mempelajari dan menganalisis fenomena ekonomi dibutuhkan model atau teori. Fungsi model atau teori adalah untuk membantu dalam menjelaskan fenomena-fenomena ekonomi. Model ekonomi makro yang sering digunakan untuk menganalisis bagaimana kebijakan fiskal dan moneter bekerja dalam perekonomian terbuka adalah Model Mundell-Fleming. Model tersebut biasa juga disebut dengan model IS-LM-BP (Makin, 2002). Dalam model IS-LM-BP, instrumen kebijakan fiskal yang biasa digunakan adalah pengeluaran pemerintah dan pajak. Sedangkan instrument kebijakan moneter yang biasa digunakan adalah jumlah uang beredar (JUB) domestik. (Sugiyanto, 2004). (Mankiw, 2003) mengemukakan bahwa Model Mundell-Fleming membuat satu asumsi penting dan ekstrem, yakni model ini mengasumsikan bahwa model yang sedang di pelajari adalah perekonomian kecil terbuka dengan aliran modal sempurna. (Santoso, 2009)

Dengan keterbukaan ekonomi yang semakin lebar dan terjadinya peningkatan aliran modal ke Indonesia sehingga memberikan peran penting terhadap pertumbuhan ekonomi dan investasi, namun dengan terjadinya peningkatan aliran modal yang masuk ke Indonesia akan berpengaruh terhadap beberapa indikator makro ekonomi, seperti: nilai tukar dan inflasi. Definisi perekonomian kecil terbuka adalah suatu perekonomian merupakan bagian kecil dari perekonomian dunia, dan dengan sendirinya tidak memiliki dampak yang berarti terhadap tingkat bunga dunia. Dengan 
mobilitas sempurna, dapat diartikan bahwa penduduk suatu negara dapat memiliki akses penuh ke pasar uang dunia. Dengan asumsi mobilitas modal sempurna tersebut, tingkat bunga dalam perekonomaian kecil terbuka (r), harus sama dengan tingkat bunga dunia (world interest rate).

Kurva LM menyatakan hubungan antara tingkat bunga dan tingkat pendapatan yang muncul di pasar uang (Mankiw, 2003). Menarik melihat pada perekonomian Indonesia bagaimana perubahan tingkat pendapatan yang terjadi pada perekomian Indonesia pada kondisi perekonomian terbuka. Berdasarkan perumusan masalah tersebut, analisis shocks kebijakan moneter dalam perekonomian terbuka terhadap variabel-variabel makroekonomi seperti tingkat inflasi, suku bunga, nilai tukar riil, dan permintaan uang perlu dilakukan. Di mana variabel variabel tersebut merupakan determinan dalam pasar uang (LM). (Case, 2006) juga mendefinisikan bunga sebagai biaya peluang untuk memegang uang. Semakin tingginya tingkat bunga, semakin tinggi pula biaya peluang memegang uang dan semakin sedikit uang yang ingin dipegang orang. Hal ini memberikan kesimpulan bahwa ketika tingkat bunga tinggi, orang ingin mengambil keuntungan penghasilan tinggi dari obligasi, sehingga mereka memilih memegang sedikit uang. Dengan demikian, tingkat bunga memiliki dampak terhadap inflasi dengan mempengaruhi spekulasi para pelaku ekonomi. Pertumbuhan uang yang tinggi berdampak pada inflasi yang tinggi pula. Jika uang beredar terus tumbuh, tingkat harga juga akan terus meningkat. Pendapat lain dari (Thronton \& Jaeger, 2007) menjelaskan bahwa otoritas moneter memiliki insentif untuk membuat sebuah shock inflasi atau inflation surprise yang akan mendorong pertumbuhan ekonomi, peningkatan pada pertumbuhan jumlah uang, dan inflasi juga akan meningkatkan tingkat inflasi rata-rata.

Tingkat inflasi suatu negara merupakan satu dari sebagian variabel penting yang perlu diperhatian dalam perekonomian. Tingkat inflasi domestik yang lebih tinggi dibanding dengan tingkat inflasi di negara yang lain juga akan menjadikan tingkat bunga domestik riil menjadi tidak kompetitif sehingga dapat memberikan tekanan kepada nilai tukar rupiah, sehingga rupiah terdepresiasi terhadap mata uang asing, terutama mata uang dollar sebagai mata uang utama dalam proses perdagangan internasional. Pengaruh nilai tukar terhadap inflasi bisa terjadi baik secara langsung (direct exchange rate pass through) maupun secara tidak langsung (indirect exchange rate passthrough). Pengaruh secara langsung terjadi apabila perkembangan nilai tukar berpengaruh pada pola pembentukan harga oleh perusahaan serta ekspektasi inflasi masyarakat, khususnya terhadap barang impor. Pengaruh secara tidak langsungnya terjadi karena perubahan nilai tukar mampu berpengaruh terhadap komponen ekspor dan impor dalam permintaan aggregat. Perkembangan ini akan berdampak kepada besarnya output riil yang pada akhirnya mampu menentukan tekanan inflasi dari sisi kesenjangan output.

\section{METODE PENELITIAN}

Penelitian ini merupakan penelitian deskriptif kuantitatif yang berusaha menggambarkan ekonomi makro Indonesia dengan variabel yang representatif. Penelitian ini menggunakan pendekatan kuantitatif dalam menganalisis hubungan simultan antar variabel moneter dalam perekonomian terbuka terhadap variabel-variabel makroekonomi moneter di Indonesia dengan menggunakan persamaan simultan. Data yang digunakan dalam penelitian ini menggunakan data sekunder yang diperoleh dari instansi pemerintah, Badan Pusat Statisti (BPS), Statistik Ekonomi Keuangan Indonesia (SEKI) Bank Indonesia, International Monetary Fund (IMF), Federal Reserve (The Fed) dan US Energy Information Administration serta dari berbagai jurnal. Data yang dipakai adalah data bulanan dengan rentang waktu 2001:01 sampai 2019:08. 
Jurnal Ekonomi \& Pendidikan, 18(1), 2021

Model yang digunakan adalah persamaan simultan dimana terdapat dua persamaan menggunakan pendekatan Two Stage Least Square (TSLS) karena untuk mengetahui tingkat korelasi dan pengaruh yang terjadi dalam model. Metode TSLS adalah metode yang umum digunakan untuk mengestimasi persamaan simultan. Metode ini digunakan ketika model persamaan simultan adalah terlalu teridentifikasi (Widarjono, 2013). Menurut (Gujarati, 2003) metode TSLS khusus dibuat untuk model yg terlalu teridentifikasi, namun tetap dapat digunakan untuk persamaanpersamaan yang tepat teridentifikasi. Ide dasar dari TSLS adalah menggantikan variabel endogen yang stokastik dengan sebuah kombinasi linier dari variabel yang telah ditentukan dalam model. Dengan demikian membentuk metode instrumental variabel dimana dalam estimasi variabelvariabel yang telah ditentukan akan bertindak sebagai instrument atau proxy untuk variabel endogen. Variabel-variabel yang digunakan dalam penelitian ini meliputi tingkat SBI rate (R) dan inflasi (INF), dan sebagai variabel endogen, serta menggunakan variabel instrumental nilai tukar (ER), Aset Luar Negeri Bersih (NFA), harga minyak dunia (OP), permintaan uang (MD) dan Indeks Produksi Indonesia (IPI).

Model ekonometrika yang digunakan dalam penelitian ini adalah model persamaan simultan yang terdiri atas dua persamaan perilaku, yakni: Persamaan Tingkat Bunga dan Persamaan Inflasi. Model makroekonometrika selengkapnya adalah:

1. Persamaan Tingkat Bunga:

$$
\begin{gathered}
\mathrm{R}=\mathrm{f}(\mathrm{MD}, \mathrm{ER}, \mathrm{OP}, \mathrm{IPI}, \mathrm{INF}) \\
\mathrm{R}_{\mathrm{t}}=\alpha_{10} \mathrm{MD}_{\mathrm{t}}+\alpha_{11} \mathrm{ER}_{\mathrm{t}}+\alpha_{12} \mathrm{OP}_{\mathrm{t}}+\alpha_{13} \mathrm{IPI}_{\mathrm{t}}+\alpha_{14} \mathrm{INF}_{\mathrm{t}}+\varepsilon_{1 \mathrm{t}}
\end{gathered}
$$

2. Persamaan Inflasi:$$
\mathrm{INF}=\mathrm{f}(\mathrm{IPI}, \mathrm{MD}, \mathrm{OP}, \mathrm{R}, \mathrm{NFA})
$$$$
\mathrm{INF}_{\mathrm{t}}=\alpha_{20} \mathrm{IPI}_{\mathrm{t}}+\alpha_{11} \mathrm{MD}_{\mathrm{t}}+\alpha_{12} \mathrm{OP}_{\mathrm{t}}+\alpha_{13} \mathrm{R}_{\mathrm{t}}+\alpha_{14} \mathrm{NFA}_{\mathrm{t}}+\varepsilon_{1 \mathrm{t}}
$$

Dengan 5 variabel eksogen atau predetermined variabel atau instrumental variabel sebagai berikut:

Persamaan Pendapatan Nasional

Persamaan aktiva luar negeri bersih

Persamaan harga minyak dunia

Persamaan Nilai Tukar

Persamaan Permintaan Uang

Dimana:

$\mathrm{R}$

INF

MD

ER

IPI

OP

NFA

$$
\begin{aligned}
& \mathrm{IPI}=\mathrm{IPI}^{0} \\
& \mathrm{NFA}=\mathrm{NFA}^{0} \\
& \mathrm{OP}=\mathrm{OP}^{0} \\
& \mathrm{ER}=\mathrm{ER}^{0} \\
& \mathrm{MD}=\mathrm{MD}^{0}
\end{aligned}
$$

Semua data tersebut merupakan data bulanan sehingga diperoleh jumlah $\mathrm{n}$ data yang cukup memadai. 


\section{HASIL DAN PEMBAHASAN}

Sebelum dilakukan pembahassan terhadap hasil regresi hendaknya dilakukan pengujian dahulu terhadap penyimpangan asumsi klasik. Pengujian tersebut dilakukan untuk menghasilkan penaksir yang BLUE. Uji ekonometri yang perlu dilakukan adalah uji autokorelasi, uji heteroskedastisitas dan uji multikolinearitas. Uji heteroskedastisitas dilakukan dengan menggunakan metode white test atau Jaque-Berra. Dalam mendeteksi autokorelasi pada model regresi menggunakan metode BrueschGodfrey - LM test. Uji ini mampu mengakomodasi apabila dalam suatu model regresi terdapat variabel independen yang bersifat nonstokastik seperti variabel dengan unsur lag. Dengan membandingkan besarnya nilai $\chi 2$ estimasi dan $\chi 2$ tabel akan dapat diketahui bahwa apakah persamaan lolos pengujian autokorelasi atau tidak. Jika nilai $\chi$-squared estimsi lebih kecil dari nilai $\chi 2$ (chi-squared) tabel berarti tidak ada masalah serius dengan autokorelasi. Sedangkan untuk mendeteksi masalah multikolinieritas suatu model regresi dengan menguji koefisien korelasi antar variabel independen (Donald \& Glauber, 1967). Dalam tulisan ini tidak akan ditampilkan hasil regresi persamaan struktural, yang ditampilkan hanya regresi persamaan struktural yang sudah terbebas dari uji asumsi klasik. Untuk hasil uji autokorelasi, uji heteroskedastisitas dan uji multikolinearitas dapat dilihat pada tabel berikut:

Tabel 1. Hasil Pengujian Autokorelasi, Heteroskedastisitas dan Multikolinearitas

\begin{tabular}{|c|c|c|c|}
\hline Persamaan & Multikolinieritas & Heteroskedastisitas & Autokorelasi \\
\hline Tingkat Bunga & $\begin{array}{c}\text { LMD - LNFA : } \\
0.983044536\end{array}$ & Homoskedastisitas & Non-Autokorelasi \\
\hline Inflasi & Non-multikoinieritas & Homoskedastisitas & Non-Autokorelasi \\
\hline
\end{tabular}

Permasalahan identifikasi dalam persamaan simultan merupakan hal yang penting untuk dapat sampai pada proses estimasi parameter dan analisa ekonomi selanjutnya. Masalah identifikasi artinya bahwa estimasi parameter persamaan struktural dapat diperoleh dari koefisien reduced form estimated. Jika langkah ini dapat diatasi artinya persamaan tersebut dapat diidentifikasi dan jika langkah di atas tidak dapat dilalui artinya bahwa persamaan tersebut tidak dapat diidentifikasi. Permasalahan identifikasi dilakukan karena dari suatu himpunan data yang sama dapat diperoleh taksiran koefisien dari fungsi/model/hipotesis yang berbeda. Untuk mengetahui apakah suatu persamaan dalam persamaan simultan dapat diidentifikasi atau tidak dapat diuji dapat ditinjau melalui metode pengujian order condition yang merupakan syarat perlu (necessary condition) dan rank condition yang merupakan syarat cukup (sufficient condition).

Metode pengujian order condition merupakan prasyarat perlu untuk dapat mengidentifikasi suatu model persamaan simultan. Suatu persamaan dikatakan dapat diidentifikasi manakala persamaan tersebut memenuhi ketentuan sebagai berikut:

$$
\mathrm{K}-\mathrm{k} \mathrm{m}-1
$$

dimana:

$\mathrm{K}=$ Jumlah variable yang ditetapkan lebih dahulu (predetermined variable) dalam model

$\mathrm{k}=$ Jumlah predetermined variable dalam persamaan yang diestimasi

$\mathrm{m}=$ Jumlah variable endogen dalam persamaan yang diestimasi

Ketentuan dalam identifikasi suatu model persamaan adalah:

Jika $\mathrm{K}-\mathrm{k}>\mathrm{m}-1$ disebut overidentified 
Jika $\mathrm{K}-\mathrm{k}=\mathrm{m}-1$ disebut just/exact identified

Jika $\mathrm{K}-\mathrm{k}<\mathrm{m}-1$ disebut underidentified

Dari model persamaan simultan di atas kemudian dilakukan uji permasalahan identifikasi untuk memenuhi kondisi order dan kondisi rank. Hasil uji identifikasi pada persamaan simultan diperoleh informasi sebagaimana nampak dalam Tabel 1. Fungsi persamaan dalam suatu model dikatakan dapat diidentifikasi manakala persamaan tersebut memenuhi kondisi overidentified atau just/exact identified. Sedangkan persamaan yang kondisinya underidentified tidak dapat diidentifikasi.

Tabel 2. Uji Identifikasi Persamaan Simultan

\begin{tabular}{llll}
\hline Persamaan struktural & K $-\mathbf{k}$ & $\mathbf{m}-\mathbf{1}$ & Kondisi order \\
\hline Fungsi tingkat bunga & $7-4$ & $2-1$ & Overidentified \\
Fungsi inflasi & $7-4$ & $2-1$ & Overidentified \\
\hline
\end{tabular}

Dari hasil uji identifikasi diatas, diperoleh bahwa kedua persamaan simultan pada penelitian ini yakni fungsi tingkat bunga dan fungsi inflasi mempunyai kondisi yang terlalu identifikasi (overidentified) sehingga dapat dilakukan estimasi.

Dalam tabel berikut ini, disajikan hasil estimasi persamaan dua fungsi tingkat bunga dan inflasi.

Tabel 3. Rangkuman Estimasi Persamaan Simultan

\begin{tabular}{cccccc}
\hline \multicolumn{5}{c}{ Persamaan Tingkat Bunga } \\
\hline Variabel & Koefisien & t-statistik & Probabiltas & R2 & F-statistik \\
C & 102.9788 & 3.938780 & 0.0001 & 0.644628 & 15.37412 \\
LMD & -7.429968 & -3.449304 & 0.0007 & & \\
ER & 0.001410 & 2.808261 & 0.0054 & & \\
OP & 0.027930 & 0.969019 & 0.3336 & & \\
IPI & -0.099595 & -1.640626 & 0.1023 & & \\
INF & -4.418559 & -1.591610 & 0.1129 &
\end{tabular}

Persamaan Inflasi

\begin{tabular}{cccccc}
\hline Variabel & Koefisien & t-statistik & Probabiltas & R2 & F-statistik \\
C & -1.160728 & -0.355868 & 0.7223 & 0.032788 & 4.781743 \\
IPI & -0.006662 & -0.620241 & 0.5357 & & \\
LMD & 1.225138 & 2.352594 & 0.0195 & & \\
OP & 0.010861 & 2.823367 & 0.0052 & & \\
R & 0.113882 & 1.648632 & 0.1007 & & \\
LNFA & -1.334484 & -2.756426 & 0.0063 & & \\
\hline
\end{tabular}

Hasil estimasi pada persamaan struktural tingkat bunga $(\mathrm{R})$ menunjukkan bahwa hubungan antara variabel dalam persamaan struktural dan variabel instrumen menunjukkan hasil sesuai dengan teori yang menjadi pijakan. Jumlah uang beredar/permintaan uang LMD, Indeks Produksi Indonesia IPI dan inflasi INF mempunyai hubungan negatif masing-masing -7,43, dan signifikan 
pada tingkat signifikansi 5 persen, -0,10 dan signifikan pada tingkat signifikansi 10 persen dan $-4,42$ mendekati signifikansi 10 persen. Nilai tukar rupiah ER, harga minyak dunia OP mempunyai nilai positif masing-masing 0,001 dan 0,03 dan masing-masing signifikan pada tingkat signifikansi 5 persen.

Dalam penelitian ini, nilai koefisien dari variabel jumlah uang beredar adalah -7,43, jika jumlah permintaan uang 1 persen maka tingkat bunga akan turun. Semakin tinggi jumlah uang yang beredar (dalam arti luas) di masyarakat maka suku bunga BI rate maupun suku bunga bank umum akan turun, hal ini berkaitan dengan teori moneter bahwa apabila permintaan uang naik, maka suku bunga akan naik untuk menjaga stabilitas harga/inflasi. Berdasarkan model Mundell-Flemming dengan perekonomian terbuka dan nilai tukar fleksibel, jika otoritas moneter dalam hal ini B1 mengeluarkan kebijakan moneter berupa peningkatan jumlah uang beredar (MD), mempengaruhi perekonomian, maka akan mendorong terjadinya penurunan suku bunga riil.

Demikian juga dengan PDB yang diproksikan dengan IPI, apabila PDB turun maka akan meningkatkan tingkat bunga. Penurunan suku bunga riil ini akan menyebabkan tingkat pengembalian domestik dari investasi keuangan asing menurun, akibatnya terjadi capital outflows yang selanjutnya mendorong terjadinya depresiasi nilai tukar rupiah. Nilai tukar dalam persamaan bunga mempunyai tanda positif 0,001 dan signifikan. Meskipun mempunyai koefisien yang kecil, artinya mempunyai pengaruh yang relatif kecil naiknya nilai tukar/apresiasi akan mengerek suku bunga bunga acuan ke angka yang lebih tinggi. Mekanisme ini dapat berlangsung secara alamiah sebagai reaksi berubahnya nilai tukar ataupun kebijakan BI dalam merespon fluktuasi nilai tukar rupiah. Sebagai negara dengan perekonomian terbuka dan termasuk kategori negara kecil, Indonesia sekarang sebagai negara pengimpor minyak, makanya adanya shock harga minyak mentah dunia (OP) akan berpengaruh positif dan signifikan sebesar 0,01. Meskipun kecil kenaikan harga minyak akan memaksa Bank Indonesia menaikkan suku bunga acuan. Variabel ini terkait dengan fluktuasi nilai tukar rupiah, dimana kenaikan harga minyak bumi (OP) akan mempengaruhi keseimbangan di pasar valut asing.

Koefisien berikutnya yang mempunyai nilai besar dan signifikan adalah inflasi (INF) sebesar 4, 42. Dapat dijelaskan turunnya inflasi akan menyebabkan tingkat bunga naik, hal ini berkaitan dengan teori bunga, dimana suku bunga riil merupakan suku bunga niminal dikurangi dengan inflasi. Apabila inflasinya turun, maka otomatis suku bunga riilnya naik. Dari persamaan simultan tingkat bunga dapat dijelaskan bahwa semua variabel yang dimasukkan dalam persamaan struktural mempunyai hubungan yang erat dan saling mempengaruhi. Meskipun hanya memasukkan dua variabel endogen, akan tetapi lebih banyak memasukkan variabel eksogen maka dapat disimpulkan bahwa sektor moneter tidak imun dari pengaruh variabel makroekonomi lainnya seperti harga minyak dan pendapatan nasional.

Meskipun dalam persamaan tingkat bunga di sini mengacu pada pembentukan tingkat bunga pada model Mundell-Fleming. Variabel inflasi merupakan komponen resiko dalam persamaan tingkat bunga dalam model Mundell-Fleming. Karena semakin tinggi laju inflasi, akan semakin menurunkan nilai riil dari tingkat bunga, sehingga return dari portofolio yang diharapkan akan semakin berkurang. Selain itu, sesuai dengan Fisher Effect bahwa naik turunnya tingkat bunga, akan menyesuaikan dengan naik turunnya laju inflasi. Berdasarkan teori ekpektasi inflasi forward looking, ketika ekspektasi masyarakat bahwa inflasi akan meningkat dari sisi konsumen maka akan terjadi penurunan permintaan, sehingga uang yang dipegang masyarakat meningkat karena daya belinya turun dan masyarakat memilih memegang uang dalam bentuk tunai (Santoso, 2009). Untuk 
menghindari inflasi yang semakin tinggi, bank sentral meningkatkan suku bunga. Variabel depresiasi nilai tukar rupiah (kurs dollar) juga merupakan komponen premi resiko dalam persamaan tingkat bunga. Depresiasi nilai tukar sekarang merupakan dasar bahwa masyarakat akan berekspektasi bahwa nilai tukar akan kehilangan nilainya (terdepresiasi) dalam waktu mendatang. Jika masyarakat berharap bahwa kurs Dollar turun (Rupiah apresiasi) dan sebaliknya, maka pinjaman yang dibuat dalam Dollar nilainya akan semakin menurun dalam pengembaliaanya dan sebaliknya. Untuk mengkompensasi penurunan mata uang Dollar tersebut, tingkat bunga di Indonesia akan lebih tinggi dari pada tingkat bunga Amerika Serikat.

Sedangkan pada persamaan inflasi semua variabel independen signifikan kecuali IPI. Variabel suku bunga secara simultan mempengaruhi inflasi, sebagaimana dalam persamaan tingkat bunga. Akan tetapi mempunyai hasil koefisien yang berbeda yakni positif, naiknya suku bunga akan menekan laju inflasi meskipun kecil jumlahnya. Hal tersebut dapat terjadi karena naiknya tingkat bunga dalam masyarakat yang konsumtif tidak serta merta akan mengurangi permintaan uang dan konsumsi sebagaimana koefisien MD bertanda positif dalam model inflasi ini. Harga minyak dunia (OP) mempunyai pengaruh yang sama yaitu positif sebesar 0,01 persen, lebih kecil daripada dalam model tingkat bunga. Variabel IPI juga mempunyai hasil yang sama yaitu negatif, naiknya pendapatan nasional akan menurunkan tingkat bunga dan inflasi. Demikian juga variabel aset luar negeri bersih (NFA) mempunyai dampak negatif terhadap inflasi sebesar -1,33.

Variabel ekspektasi inflasi pada dasarnya adalah cerminan dari rigiditas harga. Jika perusahaan menilai bahwa berdasarkan pengalaman inflasi masa lalu inflasi akan tetap atau bertahan, maka perusahaan akan menaikkan harga, sehingga sebagian dari besaran inflasi pada dasarnya terjadi karena pandangan subjektif dari pelaku ekonomi mengenai apa yang akan terjadi kedepan. Perilaku pembentukan inflasi semacam ini disebut sebagai inflasi adaptif, yang terbentuk dari peristiwa-peristiwa ekonomi masa lalu yang membuatnya bertahan hingga kini. Sehingga jika terdapat hubungan positif antara ekspektasi inflasi dan inflasi sekarang, maka di Indonesia berlaku inflasi adaptif, dan juga mencerminkan terjadinya inflasi dari sisi supply (cost push inflation). Variabel PDB periode sebelumnya memberikan pengaruh positif dan signifikan terhadap kenaikan angka inflasi, meskipun koefisiennya sangat inelastis. Jika PDB periode sebelumnya meningkat, maka akan meningkatkan permintaan agregat. Apabila penawaran agregat tidak berubah maka akan mendorong naiknya tingkat inflasi yang didorong oleh tarikan permintaan (demand pull inflation). Temuan tersebut juga dapat dijelaskan dengan pendekatan IS-LM, di mana inflasi disebabkan karena pergeseran kurva IS. Pergeseran kurva IS tersebut sebagai akibat dari kenaikan konsumsi, pengeluaran pemerintah, kenaikan ekspor yang merupakan komponen pembentuk PDB (Santoso, 2009).

\section{KESIMPULAN}

Hasil analisis simultan variabel ekonomi makro sektor moneter dengan pendekatan MundelFleming menunjukkan bahwa ada hubungan simultan antara variabel endogen persamaan tingkat bunga dan inflasi. Dari model persamaan tingkat bunga semua variabel mempunyai pengaruh yang signifikan terhadap tingkat bunga kecuali harga minyak dunia (OP). hubungan negatif ditunjukkan oleh permintaan uang (MD), pendapatan nasional (IPI) dan inflasi (INF). Sedangkan dalam persamaan inflasi, hanya variabel IPI yang tidak signifikan, hubungan negatif ditunjukkan oleh IPI dan aset luar negeri bersih (NFA). 


\section{DAFTAR PUSTAKA}

Case, K. E. (2006). Case fair : prinsip-prinsip ekonomi jilid 1. Erlangga.

Donald, F., \& Glauber, R. (1967). Multicollinearity in Regression Analysis : The Problem Revisited Author ( s ): Donald E . Farrar and Robert R. Glauber Source : The Review of Economics and Statistics, Vol . 49, No . 1 ( Feb ., 1967), pp .92-107 Published by : The MIT Press Stable UR. The Review of Economic and Statistics, 49(1), 92-107. https://www.jstor.org/stable/1937887

Grilli, V., \& Milesi-Ferretti, G. M. (1995). Economic Effects and Structural Determinants of Capital Controls. IMF Staff Paper, 42, 517-551.

Gujarati, D. N. (2003). Basic Econometrics (Fourth). McGraw-Hill Higher Education.

Makin, A. J. (2002). International Macroeconomics. Addison-Wesley Longman Ltd.

Mankiw, N. G. (2003). Teori Makroekonomi. Erlangga.

Purba, M. L. (2018). Munich Personal RePEc Archive. JurnaL Ilmiah Simantek, 2(35423), Paper No. 40041, posted 17.

Retnasih, N. R., Agustin, G., \& Wulandari, D. (2016). Analisis Guncangan Eksternal Terhadap Indikator Moneter dan Makro Ekonomi Indonesia. Jurnal Ekonomi Dan Ekonomi Studi Pembangunan, 8(2), 101-113. https://doi.org/10.17977/um002v8i22016p101

Santoso, T. (2009). Dampak Kebijakan Fiskal Dan Moneter Dalam Perekonomian Indonesia : Aplikasi Model Mundell-Fleming. Jurnal Organisasi Dan Manajemen, 5.

Solikin. (2008). Kurva Phillips dan Perubahan Struktural di Indonesia : Keberadaan, Pola Pembentukan Ekspektasi, dan Linieritas. Buletin Ekonomi Moneter Dan Perbankan, 6(4), 41-76. https://doi.org/10.21098/bemp.v6i4.838

Sugiyanto. (2004). Faktor-faktor yang mempengaruhi perilaku kurs rupiah terhadap dollar Amerika di Indonesia tahun 1986-1997: Sistesis pendekatan moneter dan pendekatan portofolio. Universitas Airlangga.

Thronton, C. H., \& Jaeger, A. J. (2007). The Ceremonies and Symbols of Citizenship. April, 15-21.

Widarjono, A. (2013). Ekonometrika Pengantar dan Aplikasinya. 